УДК 338.22

\author{
Добрянська Н.А. \\ доктор економічних наук, професор \\ кафедра економічної теорії і економіки підприємства \\ E-mail: semen-198@te.net.ua \\ Нікіфорчук А.A. \\ кандидат економічних наук, доцент \\ кафедра агробізнесу, фрінансів і права \\ E-mail: alisochka_4@mail.ru \\ Ніколюк $\overline{\mathbf{O}} . \mathbf{B}$. \\ кандидат економічних наук, доцент \\ кафедра агробізнесу, фінансів і права \\ Одеський державний аграрний університет \\ вул. Пантелеймонівська, 13, м. Одеса, Україна, 65012 \\ E-mail: alenavn@te.net.ua
}

\title{
ОСНОВНІ ЕТАПИ ЕВОЛЮЦІЙНОГО РОЗВИТКУ ІНСТИТУЦІЙНОГО СЕРЕДОВИЩА ДИВЕРСИФІКОВАНИХ КОРПОРАТИВНИХ ОБ'ЄДНАНЬ
}

Визначено передумови створення ефективного інституційного середовища. Розглянуто основні етапи еволюційного розвитку інституційного середовища диверсифікованих корпоративних об'єднань. Розглянуто інституційне середовище за командно-адміністративної системи за старими партійно-номенклатурними зв'язками та передумови їх виникнення. Обґрунтовано, що використання ринкових можливостей, важелів регулювання дозволить розвивати еволюцію виробничих відносин, форм власності, правову базу економіки і її надбудовану структуру.

Ключові слова: етапи еволюційного розвитку, диверсифіковані корпоративні об'єднання (ДКО), інституційне середовище, диверсифікація.

Постановка проблеми та її зв'язок з важливими науковими та практичними завданнями. Залежно від типу інституційного середовища виявляються особливості взаємодії компаній-учасників корпоративного об'єднання, а також будується структура взаємовідносин корпорації та макроекономічного середовища. Така диференціація типів інституційних середовищ утворилася в результаті певного еволюційного розвитку.

Аналіз останніх публікацій 3 проблеми. Дослідженням теоретичних, методичних і практичних питань етапів еволюційного розвитку інституційного середовища диверсифікованих корпоративних об'єднань присвячені праці таких українських вчених, як М.Й. Малік, О.Б. Наумов, П.Т. Саблук та інших науковців.

Формулювання цілей дослідження. Мета статті - розглянути етапи еволюційного розвитку інституційного середовища диверсифікованих корпоративних об'єднань.

Виклад основних результатів та їх обгрунтування. Розглянемо основні етапи даного розвитку більш докладно. У різні періоди розвитку економіки України закладалися передумови створення ефективного інституційного середовища, але в той же час виникали певні протиріччя в системах управління діяльністю корпорацій. Кожен період уособлював нову стадію розуміння керівництвом країни економічних проблем і вироблення шляхів їх вирішення. На наш погляд, часові рамки та ключові проблеми кожного з періодів можуть бути описані таким чином. Період до 1987 р. Адміністративно-командні методи централізованого управління державною економікою перестали відповідати вимогам макроекономічної ситуації; відсторонення працівників середнього та нижнього рівня від реальної участі в управлінні підприємствами спонукало багатьох 3 них спробувати себе там, де зароджується дрібний кооперативний бізнес або індивідуальне підприємництво, а відсутність чіткої законодавчої бази і практичних знань 3 економіки призвело багатьох 3 них до швидкого банкрутства i фактичної ліквідації самостійного бізнесу. Корпоративність як система управління виробництвом все більше ототожнювалася зі звичаями ділового обороту радянської економіки, адміністративним, а не судовим регулюванням господарських спорів та викликала суперечливе ставлення підприємців-початківців.

Інституційне середовище в цей період було схоже на систему партійно-господарських активів: всі ключові пости на підприємствах розподілялися не відповідно з професіоналізмом керівників, а за старими партійно-номенклатурними зв'язками. Основою для цього послужили, на наш погляд, три причини: 
1. Відсутність вітчизняних висококваліфікованих незалежних керуючих на ринку праці.

2. Неготовність підприємств високо оплачувати кваліфіковану працю зарубіжних керуючих.

3. Залишки тоталітарного світогляду i, y зв'язку 3 цим, низьке бажання взаємного обміну накопиченим досвідом між країнами 3 розвиненою ринковою економікою і країнами колишнього соціалістичного табору.

Період з 1987 р. по 1991 р. Відцентрові сили впевнено вели до розпаду монополізованої i централізованої організації господарства; заохочувана самостійність і дозволена оренда підприємств спонукали директорський корпус до поетапного їх підпорядкування групам працівників, що розділяли позицію керівників, тобто корпоративність набувала відтінок лояльності владі. Передбачена законодавчими нормами участь колективів в управлінні підприємствами через ради трудових колективів не отримала розвитку в силу непідготовленості працівників до ефективної участі в управлінні і небажання керівників "ділитися владою".

У цей період закладалися основи корпоративності директорського корпусу і структур, наближених до партійно-номенклатурних органів управління, але вже з'явилися паростки народження інституційного середовища. Крім промислового, в Україні виник i почав розвиватися фінансовий капітал у банківському та страховому секторах економіки. 3'явилися джерела і перші інструменти накопичення капіталу.

Період з 1991 р. по 1994 р. Активна чекова приватизація, в ході якої відбувся первинний перерозподіл власності серед директорського корпусу i сформованих фінансово-банківських структур; участь у приватизації була можлива, перш за все, через відкриту i приховану співпрацю 3 адміністрацією регіонів. Створювані в ході приватизації на базі великих державних підприємств акціонерні товариства вже можна було відносити до корпорацій, але не розробленість акціонерного права, недооціненість майна, а також непідготовленість персоналу підприємств зводили управління діяльністю корпорацій до традиційних методів, які у виконанні непрофесійних менеджерів приводили до подальшого розвалу і банкрутства підприємств.

У той же час почав складатися певний корпоративний стиль взаємин окремих структур, таких, як банківський капітал, нафтогазові підприємства та інші, коли на зміну державним органам управління приходять самокеровані компанії. Відчуженість же більшості населення від активних процесів участі в управлінні власністю, втрата робочих місць і економічна безграмотність сформували негативне ставлення до всіх процесів реформування економіки.

Але саме в цей період були закладені основи справжньої корпоративності серед нових підприємницьких структур, створених молодими (освіченими, честолюбними) підприємцями, у яких було тільки два шляхи: або увійти до кооперації 3 колишніми державними структурами, або протиставити їм цивілізований бізнес, заснований на досвіді зарубіжних корпорацій. До того ж, на прийняті в корпораціях рішення почала впливати вже отримана якісна закордонна освіта в нових для української економіки сферах: на фінансовому та фондовому ринках, на ринку зобов'язань, в маркетингу, менеджменті. Активне взаємопроникнення західних і вітчизняних корпорацій, спільна робота на фондовому ринку неминуче підштовхували корпорації до розуміння особливостей корпоративного управління.

Період з 1994 р. по серпень 1998 р. - грошова приватизація в умовах прийняття законів про акціонерні товариства, ринок цінних паперів, уточнення законодавства про приватизацію. Активно формується інфраструктура ринку: інвестиційні компанії та фонди, депозитарії та реєстратори, пайові інвестиційні фонди, страхові компанії, аудиторські та консалтингові компанії, пенсійні фонди та ін. Великі зарубіжні компанії відкривають свої філії, представництва або створюють спільні фірми.

Основний тягар проблеми залучення інвестицій переміщається 3 центру на регіони. Регіональні власті приймають місцеві закони про створення страхових фондів для залучення інвестицій, а об'єктом купівлі-продажу відповідно до прийнятих регіональних законів стає земля і інші об'єкти нерухомості.

Період з серпня 1998 р. по теперішній час. Ситуація зовнішнього і внутрішнього дефолту, загальний недолік фінансових ресурсів. Втеча капіталів змушує шукати нові фінансові інструменти або нові механізми використання старих активів. Напруженість на валютному ринку поряд з повною відсутністю ринку корпоративних цінних паперів роблять регіональні фінансові інструменти практично єдиним способом захисту від інфляції та отримання доходу.

На цьому тлі проявляється слабка підготовленість менеджерів (особливо вищого ешелону управління) до вибору стратегії розвитку, залученню капіталів та інвестицій, утриманню i завоюванню ринків збуту, врахування справжньої мотивації партнерів по бізнесу. Все це призводить до подальшого перерозподілу власності, але вже на тлі акціонерів, які розуміють свої права. Зміни макроекономічної ситуації змушують вищий менеджмент вибирати одне 3 двох напрямків: або входити в контакт 3 мафіозними структурами i поступово втрачати управління, або будувати таку систему корпоративних відносин, яка дозволяла б зберегти і себе, і власність.

У кожному конкретному випадку корпорація в особі їі вищого менеджменту (а в умовах України це, як правило, самі власники) робить вибір на користь поступового включення працівників в систему ділових взаємин у сфері власності замість жорсткого управління найманим персоналом. Це становить найважливіше завдання у становленні та формуванні нормальних корпоративних відносин. У цьому зв'язку, розглянемо основні тенденції розвитку 
макроекономічного середовища, а також можливі сценарії поведінки корпорації.

Виходячи 3 усвідомлення перетворення i структурних перебудов економіки, постійних зрушень системи, ми будемо оцінювати наскільки уніфіковані або реально застосовні пропоновані наукою підходи.

Досліджуючи процеси державного управління, автор Г.В. Атаманчук [2] виділяє сформовані економікою умови:

- соціально-психологічні, які включають усвідомлення нових життєвих орієнтирів;

- діяльнісно-практичні, коли рішення, дії, операції, процедури, вчинки тощо спрямовані на досягнення цілей державної політики та здійснюються в їі руслі.

Ця точка зору на умови принципово не відрізняється від традиційної, або консервативної, як ми вважаємо, іiі більш правильно називати. Система ринкових відносин характеризує такий етап у розвитку суспільства, коли домінують матеріальноречовинні фактори, що обумовлюють уречевлення i самих відносин. Особливість теперішнього періоду розвитку суспільства повинна переходити до умов i факторів інтелектуального порядку, що буде структурно змінювати умови в напрямку пріоритетів соціально-психологічного порядку.

У силу цього сам ринок буде виступати необхідною умовою переходу на більш якісний рівень розвитку суспільства - інтелектуальноінформаційний і соціально обумовлений.

Обгрунтоване використання ринкових можливостей, важелів регулювання дозволить розвивати еволюцію виробничих відносин, форм власності, правову базу економіки і іï надбудовану структуру:

- ставити в центр уваги людину, її можливості і потреби;

- використовувати саморегульовані властивості ринкового механізму в суспільно значимих, глобальних цілях, з урахуванням світогосподарських процесів і тенденцій;

- постійно і всебічно спиратися на науковопрактичні розробки й удосконалювати базу знань суспільства.

Висновки та перспективи подальших досліджень. Нами представлені хрестоматійні умови господарювання з урахуванням умов ринку. Справа в тому, що саме елементарні правила господарської діяльності в нас не працюють, у більшості, носять формальний характер, але це зовсім не означає, що не потрібно винаходити в нових ринкових відносинах i радикально нові прийоми і правила.

\section{Література}

1. Андронов В. В. Корпоративный менеджмент в современных экономических отношениях / В. В. Андронов. - М. : Экономика. - 2003.

2. Атаманчук Г. В. Теория государственного управления : Курс лекцій / Г. В. Атаманчук. - М. : Юрид. лит. - 1997. - 400 с.

3. Басюркіна Н. Й. Особливості агропромислової інтеграції в умовах трансформації економіки (на прикладі плодоовочеконсервної галузі) / Н. Й. Басюркіна // Південноукраїнський правничий часопис : наук. журн. - Одеса. - № 3. - 2007. - С. 84-89.

4. Бугель Ю. В. Організація кредитного процесу комерційних банків в Україні / Ю. В. Бугель // Економіка: проблеми теорії та практики. Збірник наукових праць. Випуск 207 : В 5 т. Том II. Дніпропетровськ : ДНУ. - 2005. - С. 473-478.

5. Варналій 3. С. Основи підприємництва : Навч. посіб. / 3. С. Варналій. - К : Прес. - 2002. - 239 с.

6. Довгань Л. С. Управління корпораціями : Монографія. / Л. Є. Довгань, В. В. Пастухова, Л. М. Савчук. - К. : Політехніка. - 2004.

7. Корпоративне управління : Підручник. / [Мостенська Т. Л., Новак В. О., Луцький М. Г., Симоненко Ю. Г] - К.: Каравела. - 2008. - 384 с.

8. Менеджмент корпорации и корпоративное управление : Монография / Асаул А. Н., Павлов В. И., Беськиерь Ф. И., Мышко О. А. - СПб. : Гуманистика. - 2006.

9. Орехов С. А. Основы корпоративного управления : учебник. / С. А. Орехов, В. А. Селезнев. - М. : Маркет Д. С. $-2006 .-408$ с.

10. Шумпетер Й. Теория экономического развития (исследование предпринимательской прибыли, капитала, процента и цикла конъюнктуры) / Й. Шумпетер. - М. : Прогресс. - 1982. - 158 с. 


\author{
Добрянская H.A. \\ доктор экономических наук, профессор \\ кафедра экономической теории и экономики предприятия \\ E-mail: semen-198@te.net.ua \\ Никифорчук А.A. \\ кандидат экономических наук, доцент \\ кафедра агробизнеса, финансов и права \\ E-mail: alisochka4@mail.ru \\ Николюк Е.B. \\ кандидат экономических наук, доцент \\ кафедра агробизнеса, финансов и права \\ Одесский государственный аграрный университет \\ ул. Пантелеймоновская, 13, г. Одесса, Украина, 65012 \\ E-mail: alenavn@te.net.ua
}

\title{
ОСНОВНЫЕ ЭТАПЫ ЭВОЛЮЦИОННОГО РАЗВИТИЯ ИНСТИТУЦИОНАЛЬНОЙ СРЕДЫ ДИВЕРСИФИЦИРОВАННЫХ КОРПОРАТИВНЫХ ОБЪЕДИНЕНИИ
}

В разные периоды развития экономики Украины закладывались предпосылки создания эффективной институциональной среды, но в то же время возникали определенные противоречия в системах управления деятельностью корпораций. Каждый период олицетворял новую стадию понимания руководством страны экономических проблем и выработки путей их решения. Институциональная среда в этот период была похожа на систему партийно-хозяйственных активов: все ключевые посты на предприятиях распределялись не в соответствии с профессионализмом руководителей, а по старым партийно-номенклатурным связям. Основой для этого послужили, на наш взгляд, три причины: отсутствие отечественных высококвалифицированных независимых управляющих на рынке труда; неготовность предприятий высоко оплачивать квалифицированный труд зарубежных управляющих; остатки тоталитарного мировоззрения и, в связи с этим, низкое желание взаимного обмена накопленным опытом между странами с развитой рыночной экономикой и странами бывшего социалистического лагеря.

В каждом конкретном случае корпорация в лице ее высшего менеджмента (а в условиях Украины это, как правило, сами владельцы) делает выбор в пользу постепенного включения работников в систему деловых отношений в сфере собственности вместо жесткого управления наемным персоналом. Это составляет важнейшую задачу в становлении и формировании нормальных корпоративных отношений. В статье представлены хрестоматийные условия хозяйствования с учетом условий рынка. Дело в том, что именно элементарные правила хозяйственной деятельности у нас не работают, в большинстве, носят фрормальный характер, но это вовсе не означает, что не нужно изобретать в новых рыночных отношениях и радикально новые приемы и правила.

Ключевые слова: этапы эволюционного развития, диверсифицированные корпоративные объединения (ГКО), институциональная среда, диверсификация.

Dobriansky N.A.

Doctor of Economics, Professor

Department of Economics and Business Economics

E-mail: semen-198@te.net.ua

Nikiforchuk A.A.

Ph.D. in Economics, Associate Professor

Department of Agribusiness, Finance and Law

E-mail: alisochka 4@mail.ru

Nikoliuk E.V.

Ph.D. in Economics, Associate Professor

Department of Agribusiness, Finance and Law

Odessa State Agrarian University

Panteleymonovskaya Str., 13, Odessa, Ukraine, 65012

E-mail: alenavn@te.net.ua

\section{THE MAIN STAGES OF EVOLUTIONARY DEVELOPMENT OF THE INSTITUTIONAL ENVIRONMENT OF DIVERSIFIED CORPORATE GROUPS}

Pre-conditions of creation of effective institutional environment were mortgaged in different periods of development of economy of Ukraine, but at the same time there were certain contradictions in control system 
by activity of corporations. Every period personified the new stage of understanding guidance of country of economic problems and making of ways of their decision. An institutional environment in this period was look like the system of party-economic assets: all key posts on enterprises were distributed not accordingly with professionalism of leaders, but after old party-top-level copulas. For this purpose three reasons served basis, in our view, : absence of home highly skilled independent managing at the market of labor; unavailability of enterprises highly to pay skilled labor of the foreign managing; bits and pieces of totalitarian world view and, in this connection, subzero desire of mutual exchange by the accumulated experience between countries with the developed market economy and countries of former socialistic camp.

In every case a corporation in the person of her higher management (and in the conditions of Ukraine it, as a rule, proprietors) does a choice in behalf on the gradual plugging of workers in the system of business mutual relations in the field of property instead of hard management the hired personnel. It presents a major task in becoming and forming of normal corporate relations. We are present the textbook terms of ménage taking into account the terms of market. The point is that exactly the elementary rules of economic activity do not work for us, in majority, carry formal character, but it quite not means that it is not needed to invent in new market relations and radically new receptions and rules.

Keywords: stages of evolutionary development, diversified corporations (GKO), the institutional environment, diversification.

\section{References}

1. Andronov, V.V. (2003). Korporativnyj menedzhment v sovremennykh ehkonomicheskikh otnosheniyakh. [Corporate management in modern economic relationships], Ekonomika, Moscow, Russia.

2. Atamanchuk, H.V. (1997). Teoryia hosudarstvennoho upravlenyia: Kurs lektsij. [The theory of public administration: Course of lecture], Legal literature, Moscow, Russia.

3. Basyurkina, N.Y. (2007). "Features of agro-industrial integration in the transformation of the economy (for example, tinned vegetables and fruits sector)". Pivdennoukrains'kyj pravnychyj chasopys, vol. 3, pp. 84-89.

4. Bugel, U.V. "Organization of the credit process of commercial banks in Ukraine", Ekonomika: problemy teorii ta praktyky. Zbirnyk naukovykh prats, vol. 207, pp. 473-478.

5. Varnalij, Z.S. (2002). Osnovy pidpryiemnytstva: Navch. posib. [Fundamentals of entrepreneurship: Training manual], Press, Kiev, Ukraine.

6. Dovgan', L.C. (2004). Upravlinnya korporatsiyami: Monografiya. [Management Corporation: Monograph], Politekhnika, Kiev, Ukraine.

7. Mostens'ka, T.L. (2008). Korporativne upravlinnya. - Pidruchnik. [Corporate Management. - Tutorial], Karavela, Kiev, Ukraine.

8. Asaul, A.N. (2006). Menedzhment korporatsii i korporativnoe upravlenie: Monografiya. [Management of the corporation and Cooperative Management: Monohrafyya] Gumanistika.

9. Orekhov, S.A. (2006). Osnovy korporativnogo upravleniya: uchebnik. [Fundamentals of Corporate Control: Tutorial], Market DC, Moskva, Russia.

10. Schumpeter J. (1982). Teoryia ekonomycheskoho razvytyia (yssledovanye predprynymatel'skoj prybyly, kapytala, protsenta y tsykla kon'iunktury). [Theory of economic development (research of enterprise income, capital, percent and cycle of the state of affairs)], Prohress, Moskva, Russia. 